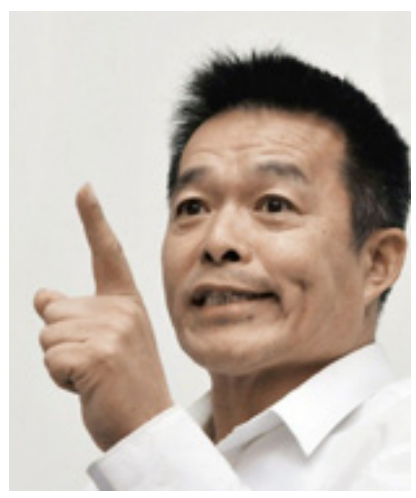

Hu Angang, PC: Handout
Hu Angang is a professor of economics at Tsinghua University's School of Public Policy and Management, where he heads the Institute for Contemporary China Studies (ICCS).

\section{Is Hu Angang Really an Ultra-nationalist? The Recent Media Controversy in Political Context}

An article appeared recently in the South China Morning Post (SCMP) concerning an open letter calling for the dismissal of 'triumphalist academic' Hu Angang, a professor at Tsinghua University (Huang 2018). The letter, addressed to Tsinghua President Qiu Yong and signed by a number of university alumni, criticises $\mathrm{Hu}$ for 'pursuing personal glory' by claiming that China has surpassed the US in terms of economic and technological strength. This position, according to the signatories, spreads fear among other countries and misleads China's leaders by overestimating national strength.

The sentiments expressed in the letter appear to have powerful backing. An editorial in the state-run newspaper Global Times appeared around the same time, also criticising Hu's 'blind over-confidence' (Shan 2018).

According to the SCMP article, such public criticism of $\mathrm{Hu}$ is likely a result of recent pressures faced by the Chinese government. Incidents such as the 'blackballing' of the Chinese telecoms giant ZTE by the US, and recent trade disputes, have caused China's officials to review their nationalistic stance, the article suggests, so expressions of overt nationalism by public figures are being reined in.

The portrayal of $\mathrm{Hu}$ in these accounts-that of a Party hack toadying to China's leaders through self-serving displays of patriotic fervour-is too easily absorbed by Western pundits, many of whom assume that the role of policy advisors in China's authoritarian regime is to 'tell the Emperor what he already thinks'. I suspect there is more going on here than meets the eye, however. As a former employee of Hu's at Tsinghua, I would like to contribute my own interpretation of events, at least as far as I can make heads or tails of them.

$\mathrm{Hu}$ is a professor of economics at Tsinghua University's School of Public Policy and Management, where he heads the Institute for Contemporary China Studies (ICCS). His Institute is involved in writing policy recommendations for the National Five-Year Plans, and has had a number of reports 


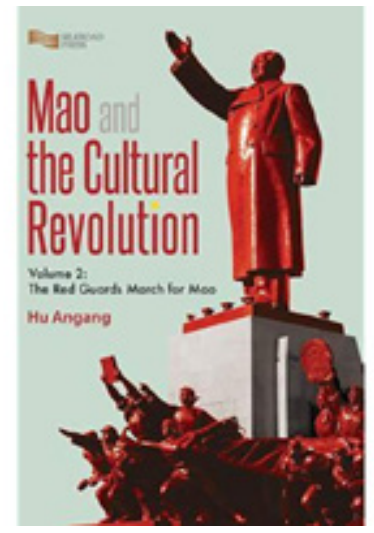

Mao and the Cultural Revolution, 2016. commissioned in recent years by the National Development and Reform Commission. In 2015, Hu's Institute was officially recognised by the Party Central Committee as one of China's first twenty-five 'national new-type think tanks', a status which guarantees that its policy reports will be fast-tracked to relevant government bureaus and receive priority attention from leading policymakers.

I was employed as a postdoctoral researcher at the ICCS from 2013 to 2016. Hu's aim in hiring me was to raise the international profile of the ICCS, and to help the Institute get publications in international (English language) peer-reviewed journals-a required criterion in Chinese university ranking systems. $\mathrm{Hu}$ is a larger-than-life character and working as his postdoc was not always plain sailing. But what struck me during my time at the Institute, albeit only through the eyes of a visiting foreigner, was the high esteem in which he is held by his closest colleagues. This stems both from his ability to garner the attention of China's top leaders, and from his willingnessmuch underestimated by external observers-to put forward unorthodox views which may divert from, and challenge, official Party doctrine.

That Hu's reports garner attention at the highest levels of the Party and government is shown by the number of pishi (comments) they receive. The pishi system allows the authors of policy reports to know if their recommendations have caught the attention of state leaders. Hundreds of reports are forwarded regularly to government and Party organs, the vast majority of which go unread. Those deemed of interest receive a pishi-usually a brief remark scrawled on the front page, such as a direction to forward the report to a particular bureau or individual, and a signature. In the past, the authors of reports had no formal way to find out if their reports had received attention unless they worked within internal government institutions. Nowadays, a formal system has been introduced whereby the pishi is scanned and relayed back to non-government think tanks such as $\mathrm{Hu}$ Angang's. Such 'comments', which are highly sought after and hard to come by, are taken very seriously by the institutions and included in the evaluation systems along with publications. Hu's Institute is known for its impressively high number of pishi, most of which are obtained by $\mathrm{Hu}$ himself. I was once shown the scan of one of these on a colleague's computer. The messy signature was $\mathrm{Li}$ Keqiang's.

Hu's willingness to challenge Party orthodoxy is evident in the case of his book, Mao and the Cultural Revolution (2016), the English version of which I proofread while his postdoc. Originally published in Chinese in 2008, the book provides Hu's own historical interpretation of the Cultural Revolution, 


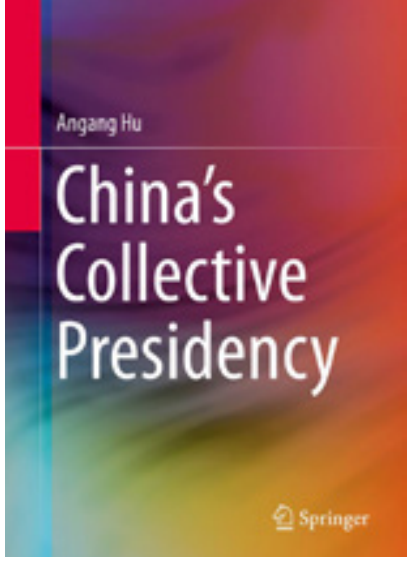

China's Collective Presidency, 2014.

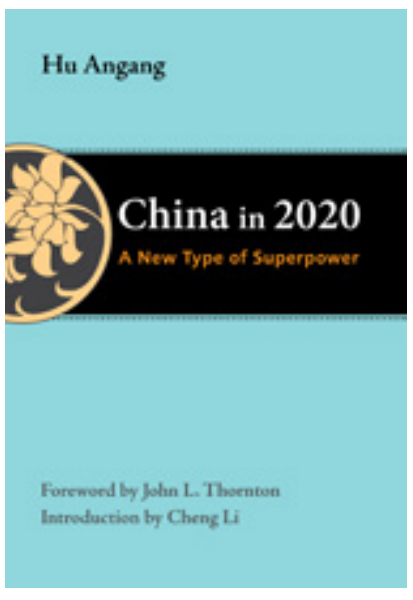

China in 2020, 2010 which deviates from the Party's official version. The book was published in Hong Kong but banned on the mainland. According to my colleagues at the Institute, following its publication, other mainland scholars waited in anticipation to see the reaction from Chinese authorities. Had it been met with approval, this would have signalled a potential broadening of accepted historical interpretations of the Cultural Revolution. As it was imparted to me, only a scholar of Hu's stature could have gotten away with writing such a book.

The general consensus from those who work closely with $\mathrm{Hu}$ is that his high praise of China and the Party in public, often perceived as ingratiation by Western commentators, is what enables him both to challenge conventional Party thinking and make robust criticisms of state policy in his internal reports, while still being taken seriously at the highest echelons of government.

Hu's book China's Collective Presidency (2014), the English version of which I also proofread while at Tsinghua, may be a case in point. $\mathrm{Hu}$ argues that the power-sharing between the nine members of the Politburo Standing Committee, all democratically elected by Party or government bodies, is superior to the tripartite and bicameral systems of the US and the UK. On the surface, the argument appears to be a nationalist polemic on the superiority of China's political system over Western liberal democracies-a reading accepted by most foreign pundits. Another interpretation is that this is a statement to Party members about the importance of guarding against the excessive concentration of power within the Party hierarchy. Research over the long term by $\mathrm{Hu}$ and others at his Institute on improving mechanisms of participation within the Party suggest that this latter interpretation takes precedence. Framing the argument as a critique of liberal democracies is, in my view, best understood as a rhetorical device to appeal to more intransigent groups within the Party.

As always, it is important to put the writings of any scholar in context and, in relation to the recent outcry over Hu's work, his record of advocating for cooperation with the US is significant. In 2009, for example, his Institute collaborated with the Brookings Institute to advocate for an agreement on climate change between Chinese leaders and the Obama administration at the Copenhagen summit. $\mathrm{Hu}$ produced an internal report in which he called on the Chinese government to heed their recent Olympic slogan-'One World, One Dream'. At the time, too many in the Chinese government were suspicious of US intentions, so Hu's endeavours were unsuccessful. 
Hu highlights a number of strategic errors made by the US. Among those mentioned, what stand out are the references to America's expansionist tendencies, its excessive expenditure on defence, and propensity to get bogged down in wars or military interventionsincluding those in Afghanistan, Iraq, Libya, and Syria.
As to his recent statements regarding China's economic and technological prowess in relation to America's, one of the articles where $\mathrm{Hu}$ makes this argument appeared in the online journal Guancha in April 2017 (Hu et al. 2017). It is entitled 'The Rise and Fall of Great Powers'. In the article, following the empirical evidence $\mathrm{Hu}$ cites in support of his claim that China has surpassed the US, is a discussion of why some powers rise while others decline. This discussion is particularly significant. Here, $\mathrm{Hu}$ highlights a number of strategic errors made by the US. The ones that stand out are the references to America's expansionist tendencies, its excessive expenditure on defence, and propensity to get bogged down in wars or military interventions-including those in Afghanistan, Iraq, Libya, and Syria. All of these, argues $\mathrm{Hu}$, have contributed to the decline of US power, and serve as a warning for a rising China.

Focussing on this aspect of Hu's argument, I think it is possible to see his claim about China surpassing the US in a different light. It is well-known among International Relations theorists that constructing the image of a more powerful enemy is a mobilising strategy used by hawkish elements to promote and justify all manner of policies and expenditures. By raising China's status in relation to the US, Hu seeks to deflate this image of the US as an imminent threat, defang those in the Party taking a more militaristic or aggressive posture who rely on this image to bolster their standing, and strengthen the position of those in policy circles arguing in favour of Sino-US cooperation. The article concludes by calling for a "new type of great power relations' based not on zero-sum games, but on the establishment of common interests.

On this basis, I disagree with the SCMP's account that criticism of Hu's statements is a sign of Chinese officials revising their former nationalistic stance. The alumni letter, for example, uses a phrase from the ancient military strategist Sun Tzu-'know yourself, know the other' (zhi ji zhi bi)-warning against the danger of over-estimating one's own strength in the face of an enemy. The Global Times' article, similarly, concludes with a warning that 'patriots... must not undermine Chinese society's efforts to unite against hegemonism.' These are not calls for humility. They are calls for vigilance-and are no less nationalistic for that. The public criticism of Hu Angang is, I suspect, not a reaction against overt displays of nationalism, but a symptom of more hawkish elements within China's leadership asserting themselves against those espousing a more conciliatory approach-as advocated by $\mathrm{Hu}$, albeit strategically couched in the language of national strength. 